\title{
O Riso e a literatura de Hilda Hilst: "a espiral não tem começo nem fim"
}

Jo A-mia

\begin{abstract}
Resumo
Esse artigo tem como objetivo falar da categoria Riso como apanágio da literatura da escritora Hilda Hilst. Processo-efeito, vislumbre de uma escrita que sem lugares para começo e fim, dá-se pela (des) ordem do riso em escalas contínuas e incessantes, cíclicas, de ritmos fugidios e permanentes: como uma espiral. Para tal, o texto foi dividido em dois momentos: primeiro, num apanhado geral acerca do conceito de riso enquanto categoria histórico-literária; e, segundo, do riso que se apropria (ou é apropriado) na/pela literatura de Hilda Hilst em escalas próprias: do riso ingênuo ao riso grotesco.
\end{abstract}

Palavras-chave: riso; literatura hilstiana; espiral. 
Muito mais vale o riso do que o pranto.

(François Rabelais)

"Sou eu esta mulher que anda comigo...?", perguntou certa vez o eu-lírico do livro Sonetos que não são. As palavras do poema bem demonstram uma das figuras mais importantes da literatura brasileira contemporânea: a escritora paulista Hilda Hilst. Representante de "uma das escritas mais estranhas que circulam na literatura em língua portuguesa atualmente" (WEINTRAUB et al., 2013), Hilda Hilst toca acordes de uma escrita densa, pretensiosa e particular. De uma literatura que passeia por reflexões "perigosas" sobre Deus, Morte, Loucura e Erotismo - o que a faz escritora universal -, não deixa de amparar-se, também, em sarcasmos, ironias e risos multifacetados.

Ao modo dos antigos (como Petrônio), essa figura da vanguarda literária brasileira empenhou-se em fazer uma "literatura séria" construída, todavia, sob o palco do riso. Riso da performance que brinca na corte como o bobo: pois ao desdizer com as palavras, repara-as com consciência luzidia. Por isso, esse artigo tem como objetivo falar do riso como apanágio da literatura hilstiana. Processo-efeito, vislumbre de uma escrita que sem lugares para começo e fim, dá-se pela (des)ordem do riso em escalas contínuas e incessantes, cíclicas, de ritmos fugidios e permanentes: como uma espiral. Para tal, gostaria de dividir essa explanação em dois momentos: primeiro, um apanhado geral acerca do conceito de riso enquanto categoria históricoliterária; e, segundo, do riso que se apropria (ou é apropriado) na/pela literatura de Hilda Hilst.

\section{Riso: categoria histórico-literária}

Pesquisas e embates teóricos vêm sendo travados acerca dos percursos da categoria Riso ao longo da história do Ocidente. Estudos como os de Henri Bergson (no livro O Riso, de 2001) e Wladimir Propp (no trabalho Comicidade e Riso, de 1983), por exemplo, defendem que o riso, no primeiro autor, é conseqüência de uma cumplicidade entre os que riem e em cuja significação social se interpõem culturas, objetos, atitudes, ditos, aparências. É mister lembrar que Bergson realiza, em seu 
tratado, uma elucubração sobre o riso cuja profundidade e força argumentativa são importantes, mas teoricamente frágeis - sua contribuição se dá, portanto, mais pelo processo poético do descrever as circunstâncias em que o riso se move que pela alçada teórica; em Vladimir Propp, por outro lado, o riso tem como ambientes o folclore e a literatura russas. Traz como premissa básica um lugar-comum a todos os estudos relacionados à trajetória histórica e literário-cultural do riso: o riso como algo intrínseco, próprio, essencialmente humano. Nesses autores, assim como a maior parte dos teóricos do riso, resvala o eco de uma imponente figura tanto para a Literatura como para a Filosofia e a História: a voz poética de Aristóteles.

Segundo Verena Alberti no livro O riso e o risivel na história do pensamento (2002, p.45), "talvez a influência de Aristóteles seja a mais marcante na história do pensamento sobre o riso": primeiro por ter afirmado que "o riso é próprio do homem"; segundo, por ter se debruçado sobre o "cômico". Por isso, não fosse a perda do Livro II da Poética, provavelmente, teríamos muito mais marcado ou valorizado o cômico e o riso na história cultural do ocidente:

Como no Livro II da Poética - aquele que, segundo o próprio Aristóteles, tratava da comédia - se perdeu, faltam-nos as idéias de Aristóteles sobre o enigma do cômico, ausência ainda mais significativa por sabermos que se ocupou do assunto. A própria perda do Livro II da Poética tornou-se objeto de reflexão. Não só foi tema apaixonante para um romance - caso de O nome da rosa, de Umberto Eco - como ocupa os círculos acadêmicos em tentativas de reconstituir o que Aristóteles teria dito. (ALBERTI, 2002, p.45)

Verena Alberti vai ainda mais longe em sua investigação filosófica sobre o riso, ao afirmar: foram Cícero (106-43 a.C) e Quintiliano (35-96 d.C) os primeiros estudiosos prováveis do riso na história do pensamento ocidental. Assim, Cícero refere-se ao ridiculum (traduzido pela autora como "risível"), na obra De Oratore, como uma importante arma no discurso de um "bom orador" - ao modo do mestre Lulius Caesar Strabo, para quem Cícero divide dois gêneros do risível: "Um se estende igualmente por todo o discurso, o outro consiste em ditos vivos e curtos. Os antigos deram ao primeiro o nome de troça (cauillatio), ao segundo, o de dito espirituoso (dicacitas)" (ALBERTI, ibid., p.57); 
já Quintiliano, no Livro VI da Institutio oratória, descreve noções significativas sobre o riso calcinado por um toque físico, um modo ou feito picante e espirituoso, pela provocação de um medo, cólera, estupidez: isto é, "fora dos limites do pensamento sério" (Ibid., p.63-67).

Outro importante trabalho sobre a Teoria do Riso pode ser encontrado no livro História do riso e do escárnio (2003), de Georges Minois - "não só por colocar-se como uma teoria que atravessa o campo da Literatura, Filosofia, História e Sociologia, mas também por circular entre outras tantas teorias do Riso" (RODRIGUES, 2009, p.11).

Inicialmente, Georges Minois faz uma fina ironia à teoria do riso presente na obra A cultura popular na Idade Média e no Renascimento (1999), de Mikhail Bakhtin: "escrevendo na URSS dos anos de 1930, Bakhtine não podia deixar de dar a sua obra contornos marxistas", revelando em Rabelais "o Marx da hilaridade, o fundador da Internacional do riso" (MINOIS, 2003, p.272). Georges Minois critica o fato de o riso ter sido relegado à margem das categorias literárias, filosóficas, históricas e culturais, ressaltando: "o riso é um caso muito sério para ser deixado para os cômicos. É por isso que, desde Aristóteles, hordas de filósofos, de historiadores, de sociólogos e de médicos, que não são nada bobos, encarregaram-se do assunto" (Id., Ibid., p.15). Depois, retoma na discussão sobre a afirmação de Aristóteles, a discriminação do riso como aporte essencialmente humano - o que deixaria para trás um estrondoso e sonoro riso cultural-simbólico, cuja culminância - a gargalhada - cria o mundo: o riso divino.

Assim, segundo Georges Minois, houve no século III um autor anônimo que escreveu um papiro alquímico conhecido por "Papiro de Leyde", cuja maior importância está na afirmação de que o universo teria nascido de uma grande gargalhada de Deus:

Tendo rido Deus, nasceram os sete deuses que governam o mundo... Quando ele gargalhou, fez-se a luz... Ele gargalhou pela segunda vez: tudo era água. Na terceira gargalhada, apareceu Hermes; na quarta, a geração; na quinta, o destino; na sexta, o tempo. Depois, pouco antes do sétimo riso, Deus inspira profundamente, mas ele ri tanto que chora, e de suas lágrimas nasce a alma (MINOIS, 2003, p.21). 
$\mathrm{O}$ criador que gargalha ecoa nos deuses protegidos no Monte Olimpo: Zeus zomba e ri de Prometeu; Apolo julga engraçados os jogos de Hermes; Atenas diverte-se em machucar Ares e Afrodite; a hilaridade contamina a vida de eternos e efêmeros (Id., ibid. p.23): desde a criação do mundo, riem os homens, riem os deuses.

Entre os romanos, o riso faz-se em dito malicioso e sarcástico que se instala nas ruas e ruínas romanas com a dicacitas:

A dicacitas é a "zombaria mordaz, o "humor pesado" que não poupa religião, raça, preferência sexual, cultura; sem limites para o riso e o escárnio abusivos e abrasivos, ela corrói o que tem pela frente; é um "humor rústico", direto, que alia riso e maltrato, deleitando-se no dissabor, na vergonha, na decepção, nos absurdos, no grotesco. (RODRIGUES, 2009, p.81)

A partir do século IV a.C., porém, o riso vai ganhando uma versão mais moderada. $\mathrm{O}$ riso alegre, inconsequente, licencioso e mordaz das festas rústicas e da bufonaria, vai, pouco a pouco, sofrendo a concorrência de um riso mais refinado e irônico. O caráter "urbano" do riso - bastante presente em Cícero e Quintiliano, bem como no refinado Sócrates, apresentado por Platão -, enfraquece sua face oposta, a face "rústica" do riso. A visão polida do riso encontra nas primeiras sistematizações um alicerce sedimentado na escola de autores do século IV a.C., composta por homens influentes, exímios oradores e pensadores requintados das sociedades gregas e romanas. As primeiras teorias sobre a difusão do riso no Ocidente, dessa maneira, remetem a Roma e Grécia antigas: sociedades onde a disposição de rir é documentada e revelada como atributo significativo.

Na Idade Média, o riso ganha novas configurações. Não é mais sarcástico e rústico, como dantes - porque prevalece na sociedade a ritualística institucionalizada da paixão e sacrifício do deus cristão -, mas sobrevive nas festas em dias de exceção, pelo carnaval. Bakhtin $n A$ cultura popular na Idade Média e no Renascimento (1999) lembra-nos que o riso é "patrimônio do povo" e, como tal, não deixou de se manifestar - apesar da vigilância e do controle religiosos característicos desse período: em meio às perscrutações religioso-moralistas, tínhamos a liturgia dos bêbados, dos jogadores, do dinheiro, as festas nos altares das catedrais - como, por exemplo, as festas do 
${ }^{1}$ Um grupo bufão formado por universitários e estudantes de diversos níveis escolares que compunham músicas satíricas, missas paródicas e remontagens alegóricas a Baco. Sabe-se que esse grupo causou bastantes transtornos e medos às autoridades porque imputavam manifestações anticlericais violentas aos seus risos sarcásticos, atacavam derrisoriamente seus políticos, esnobavam a etiqueta da nobreza, cuspiam na passividade do povo. Eram conhecidos e apontados como vagabundos, arruaceiros, mendigos, extremistas, cujo estilo de vida alternativo incomodava tanto quanto seu riso.
Asno (onde jumentos subiam ao altar e fiéis relinchavam, ao invés de responderem "amém") e dos Tontos (que imitavam os papéis representados na Corte). O riso medieval é, portanto, um riso imberbe de personalidade oscilante que se pune e que se promove nas manifestações coletivas de insatisfação (a exemplo dos goliardos ${ }^{1}$ ), nas guerras, nas brigas de poder entre monarquia e Igreja, nas contestações dos burgueses nascentes contra os privilégios da nobreza e todo o medo ocasionado pela mudança dos tempos, nas festas populares, tornando o fim da Idade Média um terreno em erosão.

Já na Modernidade o riso muda de tom e grau: intelectualiza-se. A Igreja Católica passa a ser alvo da vigilância e da pilhéria anticlerical; os bobos da corte riem cativos de seus monarcas; os loucos são enclausurados em instituições e não podem mais frequentar e brincar nas praças públicas; torna-se filosofia dos sérios e se distancia do povo. Daí, os carnavais não podem mais brincar com a mesma liberdade de antes: que se ria, mas com responsabilidade. Patrimônio da elite, o riso oficializado vai se distanciando, cada vez mais, de seu caráter originalmente "rasgado" e "vulgar" para dar lugar ao riso "polido" e "racional".

Mas uma das características históricas do riso é sua capacidade em metamorfosear-se: historicamente temos o riso como elemento constantemente passível de controle (seja pelo Império, Igreja, Monarquia ou Estado), de um lado, e, por outro, temos recorrentemente seus contrapontos impertinentes. Assim, entre os séculos XV e XVI o riso não-oficial deita raízes em figuras insolentes como François Rabelais (1490-1553): autor do livro Gargântua e Pantagruel (dividido em várias publicações separadas, mas compostas por cinco partes), humanista, anticlerical, médico e escritor, Rabelais aproveitou os mitos de Gargântua e Pantagruel (já apreciados há anos pela cultura popular francesa), para compor novas e sutis aventuras dos gigantes comilões e escatológicos. Alfinetando a realeza e a nobreza ao mostrar que ambas "descenderam de coletores de restos e de lixo", os personagens de Gargântua e Pantagruel recriam a ode carnavalesca medieval, imputando desordem, desgosto e desmonte à nova ordem social estabelecida. Seu dossiê cômico, desse modo, inaugura o riso moderno, reunindo cultura popular medieval e humor humanista intelectual. Bufão, sua única responsabilidade diante das crises foi rir; 
estudioso, relembrou a fórmula de Aristóteles que "rir é próprio do homem", fazendo com que homens e mulheres rissem, penetrando também nas literaturas universais de Boccaccio, Cervantes, Shakespeare.

Seguem daí os séculos XVII e XVIII. As brincadeiras ainda vigentes nas praças públicas passam a ser cada vez mais esquadrinhadas. Em nome da ordem pública proíbemse festas, jogos, brincadeiras. Como nos dias atuais, o poder repressor da "polícia" pretende limpar as ruas de quaisquer "algazarras" e manifestações de protestos sociais. Verdadeiramente, o que vemos nesse contexto histórico é que não há mais espaço para o carnaval. As brincadeiras em praça pública dão lugar ao divertimento no salão aristocrático. A essência pública do indivíduo transmuda-se cada vez mais em privada. Na literatura, o "realismo da alcova" substitui a representação da vida coletiva, até ao exacerbamento do espaço privado no século XIX - com a ascensão do romance e dos costumes individualizados. Entre os séculos XVII e XVIII o riso pantagruélico ou carnavalesco vai perdendo sua intensidade e legitimação, o que representa, também, uma necessidade séria, racional, cartesiana de controlar os instintos e exageros - não à toa, desaparecem ou mudam de função a figura do Bobo nas cortes: a Rainha Elisabeth, por exemplo, apesar de gostar de seus bobos, está sempre vigiando-os; o bobo, antes satírico e mordaz com a própria condição da monarquia, é domesticado e perde a graça; troca-se a rua pelos salões de festas: a elite distancia-se mais e mais do povo. $\mathrm{O}$ riso solto e travesso vai sendo substituído pelo riso irônico - mais apropriado a uma sociedade cada vez mais racional e controladora. As brincadeiras grosseiras e mordazes são pouco a pouco ocupadas pelo humor sarcástico e, por vezes, obsceno. A sátira toma a cena, irremediavelmente, destronando figuras e gargalhadas bufônicas.

Chegamos, então, à era dorisolibertino. Etimologicamente, libertino vem de libertin, escrito pela primeira vez por Calvino, em meados do século XVI, ao referir-se àqueles que promoviam a desordem religiosa. No século XVII, os libertinos constituem-se como um movimento intelectual que atinge, não só a elite letrada, mas classes menos abastadas, através, principalmente, da literatura obscena e sua revolução do corpo: a revolução libertina é a revolução do prazer livre 
dos corpos, prazer sem amarras, prazer da alma que reage e pensa com o corpo. Os libertinos chegam ao século XVIII, porém, sem a mesma vitalidade do século anterior e abraçam o Iluminismo com suas regras e preceitos anticristãos, racionalistas, materialistas e irônicos.

No século XVIII é o riso racional, eminentemente iluminista, dos livre-pensadores como Voltaire, Diderot, Hobbes, quem dará as cartas e jogará para atingir dois importantes objetivos:

Destruir: ao tentar dizimar qualquer vestígio do riso carnavalesco (já em decadência no século XVII), substituindo-lhe pelo cálido e moderado riso estratégico e inteligente, vazante nos salões de festa e espaços de convivência social; e zombar: zomba-se dos manuais e preceitos eclesiásticos, à moda de um Voltaire para quem "zombar do mundo é a única maneira de superar o absurdo": em suma, o riso satiriza por sua intelectualidade. (RODRIGUES, 2009, p.23)

Herdando o intelectualismo, o racionalismo e o caráter destruidor do século anterior, o riso que chega ao século XIX é um riso de escárnio. Permeado pelas consequências das revoluções sociais acontecidas no século XVIII (principalmente as revoluções francesa e americana), o século XIX vê o riso escarnecer da ciência, da filosofia, das instituições sociais. Filósofos como Hegel, Schopenhauer, Kierkegaard, Nietzsche teorizam sobre o riso; cientistas como Freud, poetas como Baudelaire e escritores como Victor Hugo animam-se em teorizar sobre o riso: para uns, o riso não deveria ser considerado uma categoria essencial à análise social; para outros, o riso aparece como transporte da ironia e humor que representa uma quebra dos valores arcaicos e tradicionais estabelecidos; e há, os que afirmam ainda, que o riso deve ser tomado como saída para a condição finita do ser humano em sua completa absurdez existencial.

O ser humano reificado pelo sistema capitalista e indeciso quanto à própria condição de ser-em-existência, brinda o século XX com alguns movimentos artístico-filosóficos de extrema importância não só para as artes como também para a sociedade em ebulição: futurismo, expressionismo, cubismo, dadaísmo, surrealismo. E por quê? Porque precisávamos reagir diante dos absurdos das guerras, genocídios, crises financeiras, 
religiosos fundamentalistas, terroristas, ditadores políticos, agressões à Natureza.

Assim, esses movimentos de vanguarda do século XX (além de outros como o Modernismo, Concretismo etc.) formaram um contraponto do riso na história. Tomando como sedimento os acontecimentos sociais mais significantes, os vanguardistas riram das loucuras e dos absurdos da desumanização pelos humanos. Esse riso foi um riso que gargalhou irônica e satiricamente o mundo em sua volta, penetrando e cortando feridas abertas.

Sem as brincadeiras dos carnavais medievais, menos ainda a rusticidade dos antigos romanos ou a racionalidade refinada dos iluministas, o riso ficou cada vez mais próximo de um humorismo zombeteiro e sarcástico. Nesse sentido, as formas de comunicar o riso mudam e se consagram nos séculos XX e início do XXI sob novas maneiras de expressão: histórias em quadrinhos, cinema mudo e falado, apresentações teatrais, charges, circos, mundo virtual da internet, carnavais e festas populares, livros de piadas, shows de humor. Há mais de um século essas expressões têm constituído as vidas de homens e mulheres na contemporaneidade.

\section{O riso na literatura de Hilda Hilst}

Foi Osman Lins no livro Avalovara quem afirmou: “a espiral não tem começo nem fim". Penso que a imagem da espiral simboliza bem as circunstâncias dos risos na literatura de Hilda Hilst: "como uma grande corrente em meio a águas largas e profundas, os risos passeiam pelos textos hilstianos numa escala contínua e incessante, ciclicamente, em ritmos repetidos efugidios, mas também permanentes" (RODRIGUES, 2009, p.10). Em Hilda Hilst a força do riso é inextinguível; de tamanhos e intensidades diferentes - escárnio, alegre, ingênuo, mordaz, satírico, burlesco, cáustico, bucólico, triste - "passeia livremente pelos textos dessa escritora", mesmo em momentos "politicamente incorretos" (Id., Ibid., p.205) - quando o fez em plena ditadura militar brasileira.

Para dar relevo à minha força argumentativa sobre o riso como objeto cíclico na literatura hilstiana, apresentarei, a seguir, três obras em que as escalas do riso se processam incontidamente. Como não poderei aprofundar-me em cada 
uma das obras, tentarei trazer à tona as questões que julgo mais essenciais à problematização do riso nesses textos, detendo-me, sobretudo, nas propostas conceituais ali presentes.

\section{1 - O riso ingênuo nO caderno rosa de Lori Lamby}

No Caderno rosa de Lori Lamby, livro publicado em 1990, temos a narrativa de uma menina de oito anos que escreve, no "caderno rosa" (um diário), suas "aventuras" sexuais. Aventuras que seriam amparadas pelo pai, um escritor falido, que é induzido pelo editor a produzir pornografia infantil. As cenas registradas no diário (gênero confessional oriundo do século XIX) fazem com que o leitor, pouco a pouco, compreenda a atmosfera proposta pela autora. Extravasando o "eu", através do diário, vamos percebendo as marcas da sensibilidade da personagem que, em sua ingenuidade de criança, brinca com representações de cenas pornográficas que são filtradas por seu imaginário infantil.

À primeira vista, a obra mais se parece com uma "deslavada" narrativa de pornografia infantil, depois, passamos a perceber que o texto brinca e ri do leitor ao apresentar, em primeiro plano, as cenas eróticas para esconder, em segundo plano, o que "está por trás da cena" (próprio à ritualística obscena): a recriação de uma menina a partir dos escritos do pai.

Sem deixar escapar os atos característicos da infância (o escutar atrás da porta, o mexer nos papéis deixados no escritório ou o imitar os adultos), Hilda Hilst faz de Lori uma personagem libertina que ri, ingenuamente, de toda a confusão perpetrada em sua volta - especialmente quando "descobrem" seu caderno rosa:

O riso racionalizado e ingênuo, típico dos romances libertinos - revisitado aqui por Hilda Hilst - está presente em muitos recantos de O Caderno Rosa de Lori Lamby. Amadurecido pouco a pouco com a personagem que (re)escreve o romance rejeitado pelo pai, o riso ingênuo vai derrubando barreiras contra pré-conceitos e determinações dos adultos. Falando por diminutivos e simbologias - com a linguagem característica da criança ("perninhas", "fofinha", "coxinha", "quietinha", "coisinha") - Lori, uma menina de oito anos, vai desconstruindo os estigmas e proibições envolvendo o corpo e seu mundo de prazeres. (RODRIGUES, 2009, p.24) 
Sua curiosidade aguçava-se, como qualquer criança, por aquilo que lhe era proibido. Afinal, sua maior preocupação, à semelhança do pai, era escrever e publicar seus próprios livros:

Eu ia bem de noite lá no teu escritório quando vocês dormiam, para aprender a escrever como o tio Lalau queria. (...) e todas as vezes que dava certo de eu ir lá eu lia um pouquinho dos livros e das revistinhas que estavam lá no fundo, aquelas que você e mami leem e quando eu chegava vocês fechavam as revistinhas e sempre estavam dando risada. Eu levei umas pouquinhas pro meu quarto e escondi tudo, também o caderno eu escondi lá naquele saco que tem as minhas roupinhas de neném que a mami sempre diz que vai guardar de lembrança até morrer mas nunca mexe lá (HILST, 2005, p.92).

Lori ri como quem pergunta "para que tantos escândalos"? Além do mais, que problemas poderiam surgir apenas pelo fato de ela assistir às fitas que os pais utilizavam em algumas tardes, quando se trancavam no quarto? Lori tinha o cuidado de vê-las em volume baixo, para não acordá-los. Seu riso, portanto, traz na ingenuidade a imagem exposta de um espelho que se move para todos os lados. Lori segura esse espelho, enquanto ri do desespero dos adultos que descobrem seu diário: a ingenuidade permite que a personagem não sinta culpa e passe a perna na consciência (dos adultos); que viva livremente o fluxo de seus prazeres (imaginários e reais) e aprenda com eles; e que pense, sem medo de pensar, ou seja, filosofe.

O riso ingênuo de Lori é uma arma que ataca a dissimulação daqueles que a rodeiam - especialmente os pais: "à maneira dos escritos libertinos, Lori é iniciada pelos pais, (...) ingênua, é também naturalmente disposta para a bandalheira" (PÉCORA, 2005, p.09). Ingenuidade que se torna espetáculo fino da ironia e brinca e bandalha com vários tipos de preconceitos. Em seu riso ingênuo, Lori questiona conceitos (pedofilia) e predisposições (literatura pornográfica), ressignificando-os. De uma ingenuidade que finge, também, Lori é a persona que representa o riso sobre a idiotia humana: "ao "copiar" a ficção pedófila do pai, reinventa a própria realidade" (RODRIGUES, 2009, p.71).

\section{2 - O riso rústico em Contos d'escárnio/textos grotescos}

$\mathrm{Na}$ tradição histórica (como apresentado em item anterior), o riso rústico é anterior ao riso ingênuo (característico 
${ }^{2}$ Marcus Licinius Crassus Dives (115-53 a.C) foi um general que pertenceu ao chamado "primeiro triunvirato romano", composto por Júlio César, Pompeu e Crasso; criou brigadas de incêndios - acontecimento comum na Roma antiga devido às condições inseguras e chuvas de raios nos altos prédios romanos -, recrutou um exército de trabalhadores composto por 500 homens (entre pedreiros, arquitetos e escravos) e tornou-se um grande empresário no mundo imobiliário e no empréstimo de dinheiro - aliás, uma atividade que se tornou corriqueira entre Crasso e o imperador César (CANTU, 1956; RODRIGUES, 2009) da literatura libertina). Nesse trabalho, assim como em outros que tive oportunidade de realizar, defendo a ideia de que os risos hilstianos configuram-se numa lógica própria. Lógica que não é linear, contínua, diacrônica. De outro modo, têm o seu próprio mover, o seu estar-no-mundo. Por isso, resgatam e reinventam a ordem estabelecida pelos estudos da categoria Riso. Apreendem suas características na mesma facilidade com que as abandonam.

Desse modo, tentarei resgatar nesse subitem a forma do riso rústico conhecido por dicacitas, impresso na obra Contos d'escárnio/textos grotescos (publicada em 1992). A dicacitas, de Cícero, tem por premissa o riso que flui e reverbera numa raiz antiga: o riso romano. $\mathrm{O}$ riso que revela um lado da cultura pouco explorado pela História oficial (cujo costume representa uma cultura latina com a majestade de uma sociedade pronta a adorar heróis e poetas como César, Augusto, Horácio, Cícero): as maledicências, as fofocas, as brincadeiras lúgubres e humilhantes, as galhofas romanas. A mesma sociedade das grandes arenas, dos gladiadores e imperadores - figuras icônicas da virilidade e perfeição - coexistiram com Plauto, Juvenal, Catão, Petrônio: poetas, escritores e homens que tiveram o mérito de não permitir a perda do riso e sua tradição popular:

$\mathrm{O}$ riso está presente por toda parte no mundo romano. $\mathrm{O}$ riso sob todas as suas formas, positivas e negativas, sutis e grosseiras, agressivas e indulgentes, que a língua latina concentra em uma única palavra: risus. O riso, multiforme, permanece riso: do trocadilho grosseiro ao humor mais fino, passando pelo grotesco, pelo burlesco, pela ironia, pela zombaria, pelo sarcasmo. (MINOIS, 2003, p.78).

É sob a vertente do riso romano que Hilda Hilst constrói essa ficção. Uma narrativa que tem como protagonista o personagem-narrador chamado Crasso, sessenta anos, aventureiro sexual, crítico literário, escritor. Numa longa trajetória entre amantes e experiências sexuais diversas, Crasso vai pouco a pouco tentando resolver a questão que, talvez, seja a motivadora de suas memórias: escrever. E como fazê-lo? De um lado o respeito: "sempre sonhei ser escritor. Mas tinha tal respeito pela literatura que jamais ousei" (HILST, 2002, p.14); de outro, o deboche: "é tanta bestagem em letra de forma que pensei, por que não posso escrever a minha?" (HILST, 2002, p.14). Na dúvida, ele ri. 
Crasso 1) ri da própria origem ao narrar o feito do nascimento: "minha mãe me deu tal nome porque tinha mania de ler História das Civilizações. E se impressionou muito quando leu que Crasso, um homem muito rico, romano, foi degolado e teve a cabeça entupida de ouro derretido por algum adversário de batalha e conceitos" (HILST, 2002, p.13); 2) ri e ironiza a própria existência, através da metáfora com o general/Crasso romano ${ }^{2}$, fazendo-se parte de uma fantasia identitária: "naquela época eu já era muito rico (havia bolado uma espécie de brigada de bombeiros, um empreendimento novo e negociava os serviços ou os prédios ameaçados. Torneime proprietário de vários prédios e os alugava rentavelmente" (HILST, 2002, p.17); 3) ri e se diverte com a arte da amante chamada Clódia: "as pinturas de Clódia eram vaginas imensas, algumas de densidade espessa, outras transparentes, algumas de um rubi-carmim enegrecido mas tênue, (...). A variedade de clitóris era inigualável" (HILST, 2002, p.38); 4) rimos da etimologia do nome crasso que remonta às palavras tosco, rudimentar, denso, grosso: tosco e rudimentar no trato com a vida; denso e grosso como seu sexo: "gosto muito de mulheres grandalhonas e peitudas (...) que saibam acolher um caralho" (HILST, 2002, p.15).

Crasso ri à semelhança de um ébrio; passeia pela narrativa aventurando-se insensível e seco sobre a própria vida. Rindo sarcasticamente, toma a condição do camponês latino, cujos impropérios refizeram nomenclaturas e personalidades:

O costume camponês de cobrir as pessoas de impropérios está na origem de muitos sobrenomes latinos, estigmatizando defeitos físicos, intelectuais e morais (...), o simples deslocamento de uma letra permite uma mudança de sentido cômico: M. Fulvius Nobilior, o notável, torna-se, para Catão, Mobilior, o instável (MINOIS, 2003, p.85).

Risos sarcásticos que desmarcaram e demarcam a loucura (de si e do outro). Como Fausto, o personagem Crasso também encontrou seu próprio demônio, porém, com "ligeiras" diferenças: o diabo de Crasso surgiu na figura de "um senhor de meia-idade mais pro balofo que pro atlético, linguista, e muito interessado nos esotéricos da semântica, da semiótica, da epistemologia" (HILST, 2002a., p.110). Tão logo o conhece, Crasso se entendia com o ente divino - especialmente quando tem de ouvir seus poemas infantis -, representando, 
literariamente, a iconoclastia desmesurada: nem o demônio escapa de suas inventivas de escárnio e desprezo.

No final da narrativa, temos a celebração do riso rústico através do emblema das orgias. Lembremos, através de Michel Maffesoli no livro A sombra de Dionísio (1985), que o orgiasmo é o elo de celebração das festas antigas cujo propósito de renascimento cíclico reitera a fecundidade da vida de todos (seres humanos, natureza, divindade). O riso rústico, portanto, remete-se ao fazer orgíaco dos antigos que em risos à moda de Petrônio é o riso mordaz que desfaz a ordem e a moral, fechando, simbolicamente, numa história (ou dia, ou semana) a festa do corpo: que é porco às avessas - como brinca Crasso. O riso orgiástico que grotesca a cena, próprio das saturnais ${ }^{3}$ das festas antigas em sua realidade atemporal, reaparece no final da narrativa hilstiana, representativamente, através da festa dos príncipes $\mathrm{Cul}$ de $\mathrm{Cul}$, que reproduzo em citação a seguir:

Ó céus! Fui convidado para ir à festa de casamento dos príncipes Cul de Cul e precisei, naturalmente, de uma linda peruca (...). Que festa! Que noite! Ó conas reais e olorosas, ó quantas que escondidas em rendilhadas calcinhas, em meu delírio aspirei! Devo dizer que o palácio com seus mil e novecentos quartos é o mais belo que estes meus olhos mortais já viram (...). Cuidei em comprar um penico porque nunca se sabe. Acertei. Em parte. Havia sim um banheiro de dimensões fantásticas: 300 por 300, mas penico só no outro pra mulheres. (...) E como se cagou naquela festa. E que qualidade que finura de dejetos! Caviares codornas faisões recheados de cerejas, cus de canários com amêndoas alcaparras e uvas, xerecas de gazelas, os tais tordos de Jozete, enfim tordos. ó senhores enfiar meus três dedos nos buracos de incontáveis donas e em seguida aspirar (aspirar os dedos) sob frondosas copas de imponentes árvores e algumas vezes montado nos pinheiros para que de minha tara-delícia não suspeitassem, arregacei as calças e por descuido, por imprudência (porque não olhei para baixo), defequei na peruca prateada de uma jovem esguia e ancuda, que justo naquele instante empinava

${ }^{3} \mathrm{O}$ carnaval tem origem nas saturnais. Estas eram celebrações que datam do século V a.C realizadas em homenagem ao deus Saturno - deus venerado pelos romanos por ser o portador da "ciência sagrada" e por realizar ciclos de retorno à vida (aparecendo e reaparecendo em esfera atemporal) o traseiro e dava-o a quem? Adivinharam. Ao príncipe $\mathrm{Cul}$ de Cul (HILST, 2002a., p.114).

Na festa, o riso cáustico, obsediante, orgíaco e grotesco está por toda parte, e, como nas saturnais, parece não querer cessar. O riso antigo reaparece, como o deus Saturno, reapropriado pela narrativa de Contos d'Escárnio/textos grotescos e reatualizado para chegar ao ápice da esbórnia e da brincadeira através da obra bufólicas. 


\section{3 - O riso grotesco de Bufólicas}

O livro Bufólicas, originalmente publicado em 1992 e reeditado em 2002 pela editora Globo, é um pequeno compêndio poético que à maneira dos contos de fadas narra sete pequenas histórias contadas em versos. Talvez Bufólicas possa ser considerada uma síntese entre a poesia e prosa de Hilda Hilst, "visto que guarda as temáticas e as iconoclastias da prosa, ao mesmo tempo em que apresenta um meneio preciso e infalível com as palavras, ao modo de sua poesia" (RODRIGUES, 2009, p.135). Anão, rei, rainha, chapeuzinho, maga, fada, cantora são as personagens que compõem as histórias desse poema em prosa.

Nesse sentido, tomando a etimologia do título do livro, remete-nos as palavras derivadas "bufão" ou "bufo" ao radical "buf-". Segundo Jean Chevalier e Alain Gheerbrant no Dicionário de Símbolos (2008, p.147), o bufão ou bufo tem como característica principal "exprimir em tom grave coisas anódinas e, em tom de brincadeira, as coisas mais graves". Resumidamente, esta é a proposta da obra hilstiana: pelo riso grotesco e bufônico, destronar a fantasia, a beleza, a lucidez, para dar lugar ao mágico-derrisório, à desfaçatez literária. Como uma écloga que canta em redondilhas maiores e menores, Bufólicas traz no riso a escritura de corpos e situações grotescas inimagináveis. O livro aborda sete situações diferentes - e não esqueçamos a simbologia do número sete: culto a Apolo, nas cerimônias celebradas no sétimo dia do mês; os sete emblemas de Buda; a simbologia do universo em movimento; a totalidade da vida moral em suas três virtudes teologais (fé, esperança e caridade) e as quatro virtudes cardeais (prudência, temperança, justiça e força); o número dos Céus, do poder bíblico na chave do Evangelho de São João, do sagrado para os sumerianos - dentre outras simbologias (CHEVALIER; GHEERBRANT, 2008, p.826-831).

Primeiro temos o "reizinho gay" (que assombrava a todos com seu falo gigante), depois a "rainha careca" exibindo uma "passarinha careca" (seu desgosto!); em terceiro lugar encontramos "Drida, a maga perversa e fria", vingativa; após, a "Chapéu", que descobre a vida amorosa da vovó com o lobo; em quinto plano o "anão triste", que detesta sua "terceira perna"; temos ainda a "cantora gritante", excitando os homens 
da vizinhança, e "Filó, a fadinha lésbica" (que via nascer à noite um bastão entre as pernas).

Os versos livres em rimas misturadas remontam à oralidade, à maneira das histórias contadas para se ouvir, e parodiam com muitos contos infantis sedimentados pela tradição literária. Em nenhuma outra obra de Hilda Hilst temos um riso tão mordaz, jocoso e alegre como em Bufólicas. Resgate do grotesco rabelaisiano, manifesto da blasfêmia e da heresia, destrona a puerilidade dos contos e, em seu lugar, nomeia a maledicência (quase em movimento contrário ao da narrativa de $O$ caderno Rosa), a transfiguração das personas, a formação de um novo ethos.

Numa "bricolagem do texto alheio" (SANT'ANNA, 2004), Bufólicas ri de forma fulminante sobre as estruturas, os valores e os temas tradicionais remetidos aos contos de fadas clássicos. Quer fazer rir sobre a ordem de "foram felizes para sempre" a fim de ressignificá-la pela exuberância e o exagero: o reizinho gay e o anão triste remetem-nos à sociedade falocêntrica e esquadrinhada, tão bem caracterizada pelos contos tradicionais em que o papel do homem está bem determinado e distribuído em suas funções sociais, familiares e sexuais: ambos têm falos enormes, sendo que a própria construção de uma "terceira perna" contrasta com o tamanho de seu dono (um anão!), e um corpo grotesco - o que os distancia dos protagonistas dos contos de fadas tradicionais cujos corpos "belos" e "esculpidos" pertencem a uma sublimidade mágica; temos, ainda, a fada lésbica, a maga, a Chapéu, a cantora e a rainha careca: antes de tudo, mulheres que caçoam das imagens normatizadas do corpo, do desejo e da personalidade femininas. Rindo satiricamente, as personagens femininas de Bufólicas desnaturalizam o desejo: pondo em discussão a supremacia patriarcal e o ascetismo sexual dado à mulher; $\mathrm{e}$, de modo geral, em vários lugares da narrativa, ainda, o sarcasmo contra o heterossexismo imposto, fazendo do devaneio das personagens uma força questionadora.

Narrativa transgressora, "em Bufólicas temos o mais forte e extravagante riso, o auge: há quebra, há desconforto, há imundícies, há derrisão" (RODRIGUES, 2009, p.159). Temos aqui, o mais alto e agudo dos risos porque escolhe não esquecer da bandalheira, da sordidez, da ninfomania grotesca, cujo papel 
- o de rir derrisoriamente e sem piedade - atinge a todos: dos alegres e infelizes, dos belos e feios aos grandes e pequenos.

\section{Considerações finais}

O riso é uma categoria histórico-social que vem sendo construída e reatualizada por diferentes campos de estudos (Filosofia, Literatura, História, Sociologia, Ética etc.). No campo específico da Literatura, vimos que o riso tem permeado diversas abordagens e realidades artístico-literárias, de Aristóteles, Cícero e Quintiliano aos escritores e pensadores modernos e pós-modernos como Rabelais, Bakhtin, Hilda Hilst. Não existem sociedades que não riem, existem, sim, sociedades que riem mais ou menos que outras, porque é característico do riso mascarar-se em diversos tons, gradações e formatos.

O riso é uma superfície sobreposta por muitas camadas de significações em que se dá a complexa e contraditória ritualística de viver. Mais que afirmação aristotélica para quem "rir é próprio do homem", valho-me da explanação de Rabelais que diz: "muito mais vale o riso do que o pranto", porque rir diante de todas as situações e sobre si - é um mérito.

Para dar relevo à força performática do riso, trouxe à baila algumas discussões sobre a presença do Riso na literatura de Hilda Hilst. Tentei demonstrar, em rápidas pinceladas, que o Riso tornou-se elemento fundamental na escritura hilstiana constituindo-se em diversos tamanhos e intensidades: risos de escárnio, ingênuo, burlesco, grotesco, cáustico, parodístico, libertino.

Na figura simbólica da espiral - porque os objetos de uma espiral estão em constante movimento, ascendente e descendente - procurei comprovar que o Riso em Hilda Hilst se transforma em muitos risos. Ao reler a afirmativa de Georges Minois que diz "nós rimos mais baixo e de maneira menos desenfreada que nossos ancestrais", penso que um dos grandes méritos do riso na obra de Hilda Hilst é fazer-se com intensidades tamanhas e adversas que beiram a proporções atemporais.

\section{REFERÊNCIAS}

ALBERTI, Verena. O riso e o risível: na história do pensamento. 2a . Ed. Rio De Janeiro: Jorge Zahar Ed., 2002. 
BAKHTIN, Mikhail. A cultura popular na idade média e no renascimento: o contexto de François Rabelais. $4^{\mathrm{a}}$.ed. trad. Yara Frateschi. São Paulo: Hucitec; Brasília: Editora da Universidade de Brasília, 1999.

BERGSON, Henri. O riso: ensaio sobre a significação da comicidade. São Paulo: Martins Fontes, 2001.

CANTU, Césare. História universal. Vol.5. São Paulo: Ed. das Américas, 1956.

CHEVALIER, Jean; GHEERBRANT, Alain. Dicionário de símbolos: mitos, sonhos, costumes, gestos, formas, figuras, cores, números. 22a ${ }^{\mathrm{a}}$ ed. Rio de Janeiro: José Olympio, 2008.

HILST, Hilda. O caderno rosa de Lori Lamby. São Paulo: Globo, 2005. . Bufólicas. São Paulo: Globo, 2002.

. Contos déescárnio/textos grotescos. São Paulo: Globo, 2002a.

LINS, Osman. Avalovara. São Paulo: Companhia das Letras, 2005.

MAFFESOLI, Michel. A sombra de Dionísio: sociologia da orgia. Rio de Janeiro: Graal, 1985.

MINOIS, Georges. História do riso e do escárnio. Trad. Maria Elena O. Ortiz Assumpção. São Paulo: UNESP, 2003.

PÉCORA, Alcir. Nota do organizador, In: HILST, Hilda. $O$ caderno rosa de Lori Lamby. 2a. Ed. São Paulo: Globo, 2005.

PROPP, Vladimir. Comicidade e riso. São Paulo: Ática, 1983.

RODRIGUES, Joelma. Os risos na espiral: percursos literários hilstianos. Recife: UFPE, 2009 (Tese de doutorado).

SANT'ANNA, Affonso Romano de. Paródia, paráfrase $\mathcal{E}$ cia. $7^{\text {a }}$. Ed. São Paulo: Ática, 2004.

WEINTRAUB, Fábio [Et Al.]. Os dentes da loucura, 2001. In: DINIZ, Cristiano (org). Fico besta quando me entendem: entrevistas com Hilda Hilst. São Paulo: Globo, 2013. 


\section{Abstract}

Hilda Hilst's laughter and literature: "the spiral has no beginning or end"

This article aims at discussing the category laughter as an attribute of Hilda Hilst's literature. Processeffect, glimpse of a writing that places no beginning or end, because of the (dis)order of laughter in continuous and incessant scales, cyclical, of fleeting and permanent rhythms: like a spiral. For this, the text was divided into two stages: first, an overview about the concept of laughter as historical-literary category; and, second, the laughter that appropriates (or is appropriate) in/through Hilda Hilst's literature in its own scales: from the naive laughter to the grotesque laughter.

Keywords: laughter; hilstian literature; spiral. 